\title{
Intimate Media: New Queer Documentary and the Sensory Turn
}

Jeffrey Geiger (University of Essex)

Studies in Documentary Film (forthcoming 2020), Taylor \& Francis

Print ISSN: $1750-3280$; Online ISSN: 1750-3299

DOI: $10.1080 / 17503280.2019 .1632161$

Online link: https://doi.org/10.1080/17503280.2019.1632161

The heightened visibility of LGBTQ documentaries produced from the late-1980s onwards is often viewed within the critical contexts of new queer cinema (commonly abbreviated as NQC), a term launched by B. Ruby Rich in her Village Voice and Sight and Sound articles of 1992. Rich's bold intervention picked up on an urgency among 'a new kind of film and video practice, one which takes up the aesthetic strategies that directors have already learned and applies them to a greater need than art for its own sake' (Rich 1992). Following Rich's formulation, NQC has been configured as a movement that cuts across and often confounds genres and national affiliations, 'united by a common style' which Rich characterised as 'Homo Porno' (1992). While recognising the importance of this defiance of categorisations in identifying trends across queer film and video, I want here to explore some contours of new queer documentary, ${ }^{2}$ which played such an important role in the rise of NQC. This involves further re-examining ways that queer nonfiction film and video evolved out of distinctive relations to the history and traditions of the documentary form, its established practices, and commonly-held social functions.

Queer film and video, as Bill Nichols indicated when including several key new queer titles in a 'new' and 'alternative' mode of documentary (1994: 93) — the performative - played a crucial role in shaking up the conventions and experience of documentary media. This queer work often appropriated but also fractured media standards for presenting truth and evidence, revealing what slips beyond mainstream, normalised nonfiction techniques and their established public functions. ${ }^{3} \mathrm{My}$ approach, however, stresses not just these documentaries' postmodernity and queerness in terms of content and aesthetics in relation to mainstream or (hetero)normative cinematic production - that is, the ways these films and videos went against established modes of documentary storytelling, as well as revaluating formal and informal expectations regarding how to represent sexual and gendered lives. Rather I wish to underline ways that this new queer work's intense evocations 
of sexuality and bodily sentience as experienced across private and public space, on the cusp of queer cinema's 'hypervisibility' (Dyer with Pidduck 2003: 266; Pidduck 2011), marked a crucial moment in a 'sensory turn' in practice and theory, while inhering in and transforming perceptions of objectivity, factuality, and truth in media, long associated with the documentary form.

Rich noted that the newness of NQC could be characterised as 'breaking with older humanist approaches and the films and tapes that accompanied identity politics', and pointed towards a stress on the queer body and/as physical engagement (1992). Barbara Hammer, writing in 1993, saw in her work a shift from the 'realism' of her 1970s ‘early naming and identity films' (1993: 71) towards a cinema both of abstraction and physical immersion, where 'light and texture, image and voice swirl around you and carry you into a filmic experience $[. .$.$] The active audience members$ don't lose a sense of themselves while engaging in the physical sensations of abstract cinema, but feel more the possibility of being' (Hammer 1993: 74). Hammer's essay appeared in Queer Looks, a landmark collection that aimed to capture the dynamics of a movement where 'a critical mass of artists were producing, debating, challenging' alongside 'a new militance in street politics [that] was being cross-pollinated with a new rigor in queer critical theory' (Gever, Parmar, and Greyson 1993: xiii). Critical theory and demands for alternatives to dominant codes and aesthetics that encouraged 'passive reception' (Hammer 1993: 74) had profound influence on nonfiction film and video practice - as seen in the work of Hammer, Pratibha Parmar, Trinh T. Minh-ha, Derek Jarman, and Marlon Riggs, among others-while practitioners were animating critical theory, initiating new vocabularies for thinking not just about documentary's fundamental characteristics but about relations between cinematic media and audiences more broadly. As Alexandra Juhasz aptly puts it in her mediation on New Queer Cinema, 'the integration of a theoretical practice with a media practice is definitive of and integral to media praxis: that is, media that is made in connection to an articulated project of world and self-changing'; queer cinema is an 'integrated body of cultural production' (2008: 308). Keeping this mobile and productive crosspollination in frame, I want to explore these emerging vocabularies of media practice and theory by distilling components of the new queer documentary experience that operated not in opposition to but as part of a transvaluation of documentary's longestablished associations with objectivity, factuality, and verifiable real-world events. These components, accented and probed through new queer documentaries in ways 
that often defied documentary's standard generic features, will be summed up here as: intimacy, gesture, and magnitude.

While central to the cinematic experience, intimacy, gesture, and magnitude are also transitory and personal, largely manifested through what Gilles Deleuze called the 'out of field' ('hors-champ'): that which is 'neither seen nor understood', but 'nevertheless perfectly present' (1986: 16). While invoked within discourses of desire and identification in cinema, these aspects of film experience still are not easily fixed and identified, and often embedded rather than extensively analysed in characterising documentary's forms and functions-notably in Nichols's 'modes' or 'voices' (and much new queer documentary output has been situated within the performative and poetic modes) (Nichols 1994; Nichols 2001: 134; Brasell 2015: 89). Nichols does however point the way, foregrounding the 'texture and tone' of performative documentary, which offers the possibility 'to know difference differently' (1994: 93, 97), while the poetic mode foregrounds 'mood, tone, and affect' rather than 'displays of knowledge' (2001: 103). As highlighted through an attention to nonfiction film and video by scholars such as Linda Williams (1989), Thomas Waugh (1992, 2000[1995]), José Muñoz (1995), Laura Marks (2000), Ann Cvetkovich (2002), and Roger Hallas (2009), the 'out of field', bodily, and haptic components of nonfiction cinema have emerged as central to theorising cinematic experience more broadly. A sustained focus on these components in the context of new queer documentary stresses not just how these films and videos work to trigger emotional engagement, but how they were undergirding what David Howes has labelled a transdisciplinary 'sensorial revolution' (2006: 113). Engaging LGBTQ lives often meant rejecting authoritative and 'top down' discursive practices, drawing on the margins of queer histories, experiences, and cinematic practices, working differently while not necessarily rejecting the documentary idea nor its public associations with authenticity, historical facticity, and verifiability.

Viewed within these frameworks, filmmakers key to NQC's ascendance towards hypervisibility - Barbara Hammer, Tom Joslin, and Marlon Riggs, in particular - will be explored for performing particular interventions in terms of how intimacy, gesture, and magnitude is figured and apprehended in the documentary realm. These meshings of queer practice, theory, and activism pointed towards diverse modes of cinematic engagement and a growing emphasis on the bodily, sensory, and haptic in cinema. 


\section{Signs of the times}

Keeping the transnational reach of NQC and Rich's analysis in frame, my discussion focuses on the conditions and dynamics of queer documentary in the United States, where, by the 1980s, unprecedented political interventions and attacks on independent and low-budget documentary 'propaganda' were being staged. As Patricia Zimermann argued, independent documentary was 'under siege': 'Congressional debates, political targeting by conservatives, geopolitical restructurings in the telecommunications sector, and new technologies have turned documentary into a bloody political battlefield where the casualties are mounting daily' (Zimmermann 2000: 12). The years spanning from the Reagan presidency through the 1990s, as NQC was making its mark in the US, encompassed a fraught political climate churned up by vocal members of the government hostile to efforts by factual filmmakers to communicate marginal and subcultural experiences to wider audiences. Arguably the impact and controversial visibility of new queer documentary at this point was pivotal, serving as a nexus for the deconstruction of sexual and gendered normativity, raising awareness of broader inequalities and invisibilities, posing challenges to monocultural thinking while delving further into the complexities of intersectional lives. ${ }^{4}$

Recalling that the term 'queer theory' has been traced only to the $1990,{ }^{5}$ it should be stressed that neither term 'queer' nor, for that matter, 'documentary' had (or has) a fully transparent definition: both terms might be seen as critical moving targets. My use of 'queer' here is grounded in its historical contexts, recalling the strategic repositioning of a term circulating during the 1980s and deployed in the 1990 Queer Nation manifesto as a direct-action appropriation of a word used with self-aware irony within LGBT communities while, outside of them, wielded as a term of abuse. As the manifesto, handed out at the 1990 New York City Gay Pride Day, argued:

Ah, do we really have to use that word? It's trouble. Every gay person has his or her own take on it. For some it means strange and eccentric and kind of mysterious. [...] And for others 'queer' conjures up those awful memories of adolescent suffering. Queer. It's forcibly bittersweet and quaint at bestweakening and painful at worst. (Queer Nation 1990) 
'Queer' in this sense dwells in the midst of an as-yet unresolved, culturally contested, politically dissonant, and perverse adoption of the term. 'Queer' of course has become a resilient collective concept, feeding into a range of theoretical, cultural, and artistic pursuits, developing into broader critiques of normative discourses and practices, serving as an umbrella term for diverse critical engagements in relation to sex, gender, and sexual or transgressive desire. As Douglas Crimp argues, queer was 'reclaimed' and reconfigured to forge links between theory and activism (Crimp 2002: 189). ${ }^{6}$

In the case of 'documentary', established concepts have seen the form bearing a special relationship to the manifest, pro-filmic world. Much documentary media still tend to offer thesis-driven orderings of the unpredictable and disordered realms of experience, and are afforded pedagogical value as authoritative vehicles for objectively delivering fact-based knowledge. Documentary as an agreed-upon, popularly recognised and consumed form draws on a 'rhetorical stance' that it might serve as a 'window on reality,' offering audiences an opportunity to 'encounter direct representations of the world' (Hight 2010: 16). An emphasis on facts, accuracy, evidence, and accountability — what Michael Renov has called the 'scientistic yearning' which has 'centered on the particularly vexed question of objectivity' (Renov 2004: 173)—still inheres in production, marketing, and consumption, and has been frequently traced along a genealogical line to Enlightenment demands for more precise technologies for recording facts and reporting on evidence that could advance scientific and social progress (Geiger 2011: 6).

The first wave of NQC was central in re-appropriating and repurposing the social currency of both 'queer' and 'documentary', critically reframing and reinvigorating issues of visibility and invisibility, voice and voicelessness. Many LGBTQ filmmakers such as Hammer, Parmar, Jarman, Riggs, and Isaac Julien were doing this not by staging any straightforward oppositional stance but by developing complex, dialectical means of relating centre to margins, on screen to off screen, palpable and objective evidence and facts to the more liminal regions of subjective and lived experience. In the 1980s, challenges to received assumptions about the documentary form were increasingly pressing, as high-profile debates about categorising, defining (and awarding) the work of directors such as Errol Morris and Michael Moore made clear. ${ }^{7}$ In critical theory, via post-structural and deconstructive critique, the very idea of transparency in representation was under scrutiny. At the same time, documentary as a medium for open debate and consciousness-raising was 
facing a particularly blunt New Right attacks in the US. ${ }^{8}$ The presumed political threat from liberal media was met with revised guidelines from the Reagan government for public funding. A New York Times headline gloomily predicted 'leaner times for documentaries', citing ongoing problems with fundraising and, in a move that resonates, federal directives declaring that 'any project advocating a particular program of social action or change' was ineligible for National Endowment for the Humanities (NEH) monies (Stein 1984: 25; Guenette 1987: S-26). Government attempts to block documentary broadcasts included Dark Circle (1982), about the military industrial complex, Days of Rage: The Young Palestinians (1989), which dealt with calls for a Palestinian state, and most controversially of all, Tongues Untied (1989) by Marlon T. Riggs, a director who had already subtly undermined 'PBS-style' documentary authority with Ethnic Notions (1987).

When Tongues Untied was finally broadcast in the US in July 1991, 110 out of 284 PBS stations that normally carried its flagship documentary series P.O.V. refused to air it. Revealing the social paranoia that can surface when subcultural media meet the (nearly) mainstream, most PBS stations showed it late at night along with a 'viewer advisory' citing sexually explicit content (Bullert 1997: 93). Presidential candidate Pat Buchanan linked the video to controversial art exhibitions such as the Robert Mapplethorpe retrospective touring at the time, claiming that public funds from the NEH and National Endowment for Arts (NEA) were endorsing 'pornographic art', leading to a damaged nation which 'has ceased to be a moral community' (qtd in Smith and Windes 2000: 121). The US Congress was formally pressed by Georgia Congressman and Minority Whip Newt Gingrich to eliminate federal support for public broadcasting, though only a small portion of Tongues Untied's budget (less than $\$ 8000$ ) came from a regional funding body of the NEA. If, on the surface, at issue was a reliance on public money, the larger issue lay in the status of documentary itself, as a mode 'defined and applied in relation to a sense of the "Public", and public interests (Corner 2002). A month after the broadcast, PBS cancelled another video dealing with LGBTQ issues, Stop the Church (1990), a critique of the Catholic Church's views on contraception and safe sex, made from the perspective of the direct action group ACT-UP (AIDS Coalition to Unleash Power).

These attempts to break out of the 'safe' circle of a queer subcultural audience into media outlets such as PBS were faced with politicised moral censure. But what was at stake was more profound than issues of visibility and legislated tolerance; the 
challenge lay in bridging the gap between documentary subject and wider audiences, conjuring LGBTQ lives not through authoritative facts and narrative transparency but through conveying intensely real, difficult, sentient experiences of the world. These films and videos drew on and amplified filmgoers' attentiveness to intimacy, gesture, and magnitude - liminal or threshold components of the cinematic experiencefurther reshaping how documentaries operated as modes of truthful address, reconfiguring while not erasing conceptions of documentary's immediacy, evidentiary standards, and connection to the world.

\section{Intimacy and the cinematic sensory turn}

Situated on the front line of political and aesthetic debates, negotiating prominent homophobic government and corporate interests, the documentary work of NQC's first wave emerged when nonfiction filmmaking was serving as a critical testing ground for postmodern interrogations of presumptions of universal cultural beliefs. Filmmakers were taking up the challenge of what Michael Chanan calls 'a crucial shift in the documentary idiom, almost an epistemological break, in which the old idea of objectivity is seen as naive and outmoded' (2007: 241). I would lay stress on the 'almost' here, since documentary practice broke into polyvocality and challenged a fabricated consensus, embracing experimentation, but never fully fractured into what we now call post-truth. Even with the appearance of mockumentary, conspiracy docs, and other 'fake' formats, documentary filmmakers seemed to retain core aims and beliefs that long sustained the documentary idea: desire to bear witness, to raise awareness of underexplored themes, histories, and experiences, to intervene towards social change, and to work alongside other media in the public arena to serve as flashpoints for debate and cultural revaluation. As David Harvey suggests, postmodernity as a project disconnected and unpacked sedimented cultural unities and universals — but this does not rule out the possibility to 'reconnect' (2000:16)

Barbara Hammer's Nitrate Kisses (1992) explores both a 'shift in documentary idom' and 'reconnection' through subtle convergences between experimental technique and historical-political engagement. Hammer's film embraces a deconstructive aesthetics to produce a queer cinematic space that confronts inherited cultural practices while addressing the elision of LGBTQ histories within traditional historical documentation and the archive. 


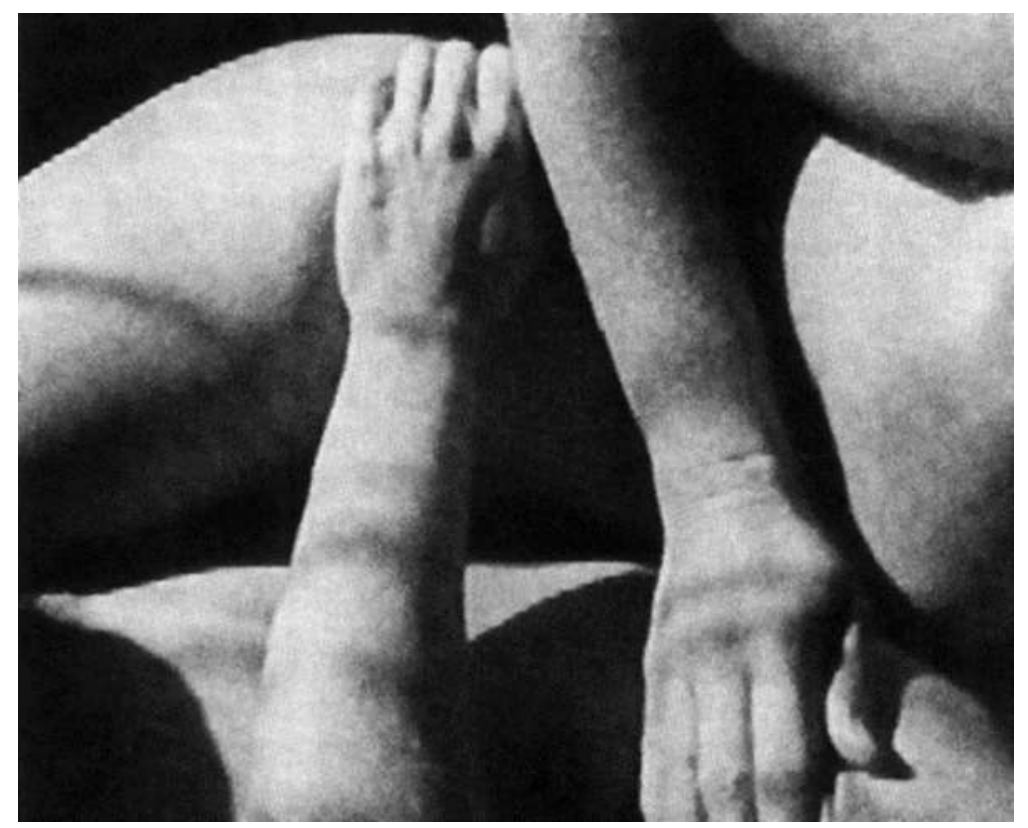

Figure 1: Nitrate Kisses (Barbara Hammer, 1992)

As Hammer noted, her approach shows the influence of Maya Deren's concept of vertical filmmaking, grounded in simultaneity rather than narrative development; her work creates impressions through imagistic layering and multiplication of associations in a single shot, and through juxtapositions (Butler and Schwartz 2010). Early in the film, black and white stock and a bleak mise-en-scène evoke the ruined or empty archive; we see popular gender stereotypes intercut with an older lesbian couple lovemaking in the ruins. Intercut through the film, such immersive shots of diverse couples serve as visceral interruptions to historical and ongoing erasures of LGBTQ experience (figure 1). The filmmaker's own shadow fleetingly appears in the montage, mapping on to a frequent use of shadow, black space, and black matte technique in new queer films such as Tongues Untied, and suggests a dialectic or over-layering of lived immediacy against the absence of inscriptions of LGBTQ lives - the filmed queer body is both vivid presence and uncanny ghost. The title, Nitrate Kisses, weds cinema's materiality (silver nitrate, ammonium nitrate) to the explosive and the sensual, rupturing the loss of private experience to history, reanimating and mediating that loss. ${ }^{9}$

As Lauren Berlant defines it, 'to intimate is to communicate with the sparest of signs and gestures, [...] Yet the inwardness of the intimate is met by corresponding publicness' (1998: 281). Hence rethinking intimacy can also be socially transformative, it 'calls out not only for redescription but for transformative analyses 
of the rhetorical and material conditions that enable hegemonic fantasies to thrive' (1998: 286). Considerations of the aesthetics and politics of intimacy have become increasingly valuable to cinema scholarship and, no less importantly, considerations of cinema itself as an 'intimate medium' (Roche and Schmitt-Pitiot 2014: 3). In Hammer's work, we find reorientations of the role of intimacy in the documentary experience, underlining not facts and evidence via realist codes in the face of historical elisions but constructing cinema spaces where 'engaging in the physical sensations' (1993: 74) becomes an extension of world experience. Impressions of intimacy can be aroused via strategic visual evocations of the body, while sound produces a sense of physical connection (noises of clothes rustling, voices close to the microphone, and so on). Such techniques work to unconceal private experience and render palpable, visibly and audibly, those spaces where the private body encounters, willingly and/or unwillingly, public engagement and display. If the documentary idea has been associated with what Carl Plantinga calls an 'assertive stance' towards objectivity and the 'actual world' (Pantinga 2009: 498), new queer documentary was working to realign this stance towards more subjective and contingent modes, experimenting in particular with making spaces where the body, visibly screened, heard, or perceived 'out of field', might be experienced as somatic engagement rather than as object or spectacle.

It should be emphasised, as Pidduck notes of NQC, that " "newness" is part of the mythology of this cycle' (2004: 83). New queer documentary's intense corporeal evocations were being exposed to much wider audiences, though not radically new, drawing on a range of feminist, lesbian, and gay experimental and nonfiction filmmaking (including Hammer's own seventies work) that focused on the duration and sensibility of the everyday, on struggles over claiming the body and bodily knowledge, and on links between physical and social experience of conflict and resistance. ${ }^{10}$ As Hammer noted of lesbian representation, 'visibility' was a central concern in the 1970s, to confront the 'blank screen' and to 'make a mark first, define a form, and make a statement that they exist' (1993: 71). In gay film and video, such as Tom Chomont's Minor Revisions (1979), Richard Dyer distinguishes 'an intimacy conveyed by the use of close-up and repetition [...] so that the overall effect is both of evanescence and intensity' (Dyer with Pidduck 2003 [1990]: 162-3). Waugh contends that 'gay male film- and video makers can be thought to have been pioneers in the arts of the body' (2000 [1995]: 243), and crucially observes that during the 'famine' years 
of queer documentary, films shared 'distinctive aesthetic strategies', in particular drawing on 'performance-based techniques' for including 'the input of subjects into the process and for filling in gaps left by conventional documentary methods' (2000 [1996]: 250). This could involve a breaking down of realist codes and, as seen in Joslin's Blackstar (1977), self-reflexively questioning film's ability to capture any 'essence' of ‘connubial intimacy' (2000 [1996]: 261).

Looking further towards experimental and surrealist precedents (such as Kenneth Anger), new queer documentaries involved a range of intersections with avant-garde film (for example Hammer's nods to Deren, and to James Sibley Watson's Lot in Sodom [1932]). Though associations with movements closely associated with realist codes played a part: in particular, interests in heightening a sense of immediacy and corporeality found in both cinéma vérité and direct cinema. These movements both experimented with techniques of intimate revelation (in direct cinema, the famous cut-away, shot from behind, of Jacqueline Kennedy's fidgeting, white-gloved fingers at a Wisconsin campaign rally, featured in Drew Associates' Primary [1960, figure 2]; in cinéma vérité, the sustained close-ups on Marilù Parolini's facial expressions and hand gestures in Chronicle of a Summer [1960]). Such techniques exposed and rendered personal the marginal, unseen, telling gestures of the body: unexpected expressions, tics, awkward reactions. With their keen interests in revelation and attention to the micro-gestural, the strategies of direct cinema and cinéma vérité pointed to the proximity of bodies on film and to the viewer's imagined body without organs: cinema technology itself.

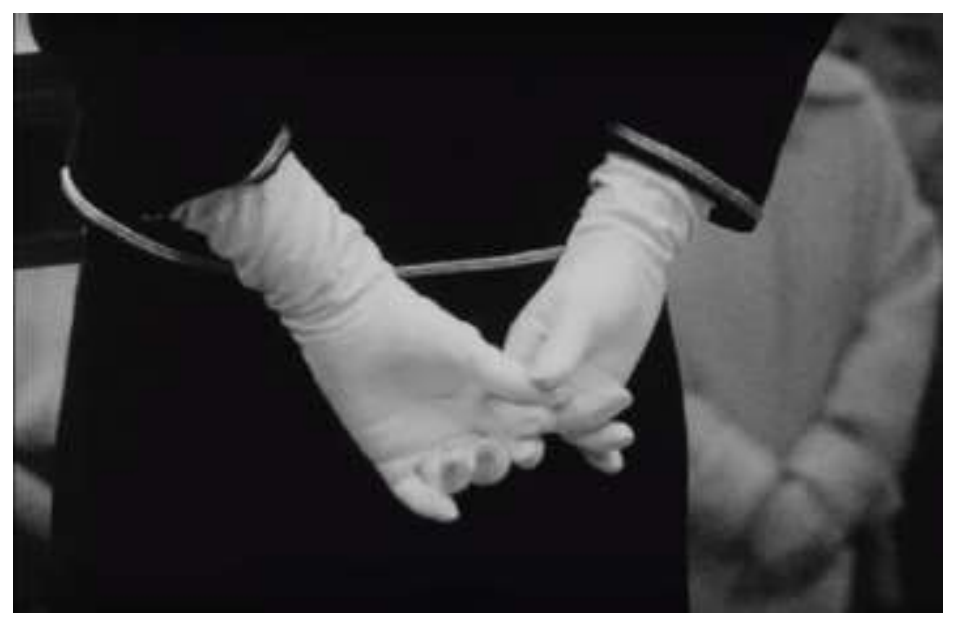

Figure 2: Primary (Drew Associates, 1960) 
We can find these lineages and their evocations of bodily intimacy in new queer documentaries such as Paris is Burning, the massive box office success of 1991 (first screened to an enthusiastic crowd of supporters and participants at the Margaret Mead ethnographic festival in New York's Museum of Natural History). Jennie Livingston's film can be viewed as a participatory celebration of gay and transgender subcultures, a key text within what Shaka McGlotten has called queer 'analogue networks' of a pre-digital, pre-internet age (2013: 5), cutting across intersectional identities and sexualities to reveal powerfully resistant, socially critical, and subversive communities. And it touched a popular nerve, displaying a subcultural LGBTQ world to mainstream audiences on a scale not achieved before. But as bell hooks observed when the wider release reached audiences in suburban multiplexes, Paris is Burning could occupy an uncomfortable space between engendering a sense of intimate knowing and enabling a disembodied or voyeuristic position. In hooks's view, the problem was rooted in depictions of 'black rituals as spectacle' (hooks 1992: 150). Paris is Burning hence incited debates about voyeurism that could inhere even in work that appears manifestly radical in content and in its politics of representation.

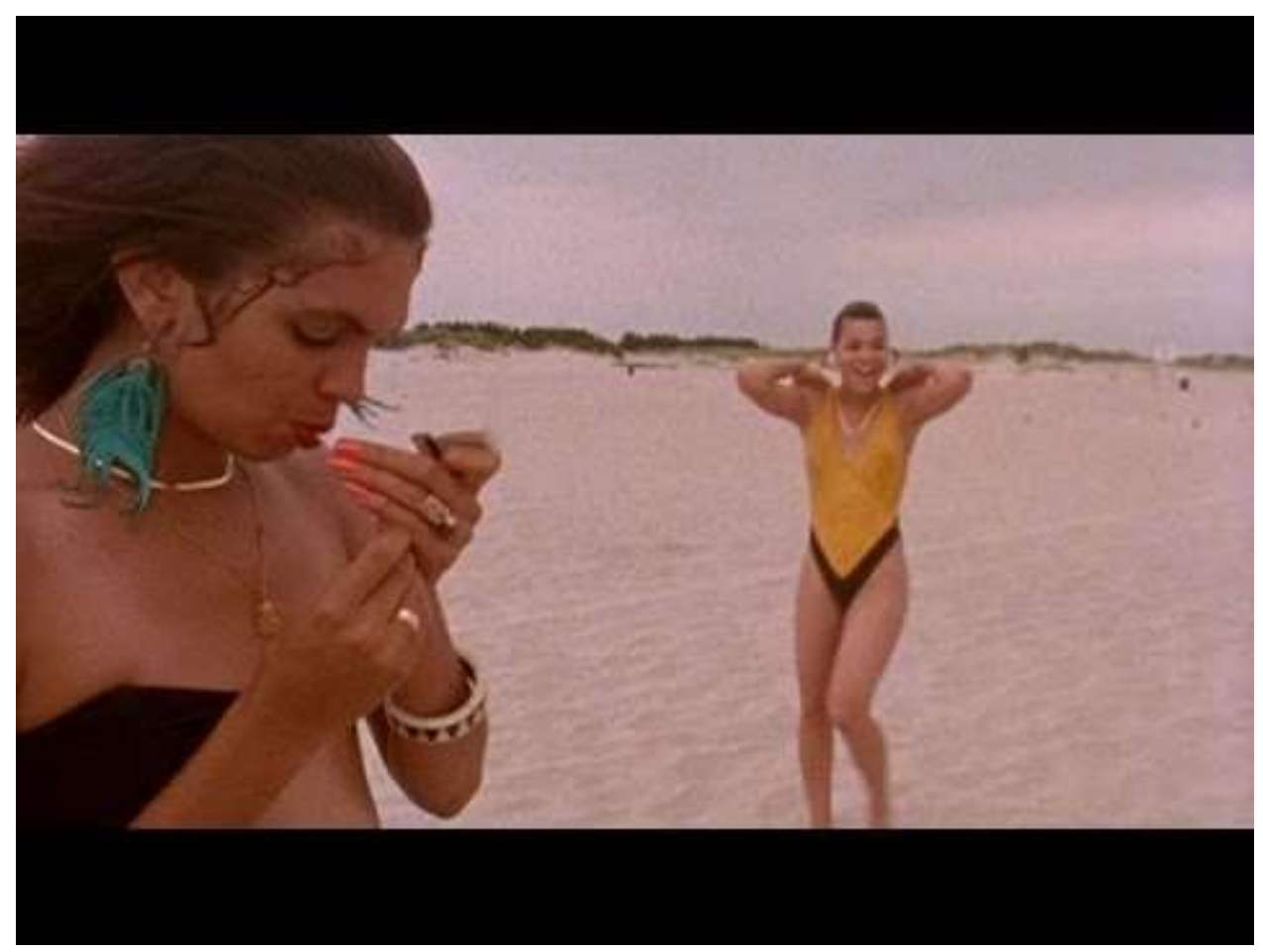

Figure 3: Paris is Burning (Jennie Livingston, 1990) 
Through its candid interviews (the scene on the beach with transitioned and transitioning women is strikingly direct and interpersonal) the film promises to produce a space of 'queer intimacy' (figure 3); but as Meredith Raimondo has observed, an intimate 'queer optic' is difficult to achieve when drawing on realist conventions (2010: 115). Paris is Burning largely puts the codes and practices of direct cinema and the ethnographic tradition to use in constructing a filmgoer positioned on the outside looking in (a subject positioning that lends itself to fictional adaptation in the series Pose [2018]). ${ }^{11}$ Such techniques in queer filmmaking inevitably 'struggle to create intimacy without resorting to forms of narrative and visual colonialism' (Raimondo 2010: 116).

Hammer's work does not capture and observe bodily presence so much as actively recast it as intimate, shared experience, exploring the liminal realms of feeling the filmed subject, of viewers sharing in forms of embodiment and subjectivity. Mapping this potential in ethnographic contexts, David MacDougall (2006) emphasises how cinema can manifest the private and intimate, though film technology has normally been associated with spectacle. Referencing neuroscience, art theory, and phenomenology, MacDougall draws visuality together with broader modalities of sense perception, indicating that cinema can tap into sensation: bodies on screen are 'as much projections of our own bodies as independent of them' (2006: 21 , italics in original). Much new queer documentary work takes this proposal a step further, posing pressing questions: is it possible to immerse filmgoers in an experience of the filmed body as sentient subject? Can audiovisual technology and technique be deployed to draw out and convey what Pidduck calls the 'intricate “substances” of queer relationality' (2009)?

Over recent decades, scholarship foregrounding the haptic and tactile properties of cinema has become increasingly prominent in theoretical discussions of cinematic affect. Vivian Sobchack's work $(1992,2004)$ has led the way, with critics and practice-based scholars such as Laura U. Marks (2000; 2002), Giuliana Bruno (2002), David MacDougall (2006), Martine Beugnet (2007), and Jennifer Barker (2009) mapping complex relations between mediated worlds and the filmgoer's multiple sensory responses. For Marks, the 'skin of film' serves as a metaphor emphasising the ways cinema can signify not just via narrative means or showing the world, but through its materiality: through forms of contact between perceivers and the world represented. Marks accentuates ways that vision itself can be tactile, as if 
viewers can in effect 'touch a film with their eyes' as we might touch a fossil; analogue images taken from life bear an indexical relationship to their absent, profilmic subjects (Marks 2000: xi). ${ }^{12}$

In ethnographic contexts, Paul Stoller noted a critical shift towards 'sensuous scholarship' (1997) while MacDougall, further expanding on visual media, observed in practice and scholarship an emphasis he called the 'sensory turn' (2006). Howes, as cited above, sums up these shifts as a transdisciplinary 'sensorial revolution' (2006: 113). ${ }^{13}$ These explorations have drawn on a phenomenological focus on sense perception and immersion most frequently developed via Henri Bergson, Maurice Merleau-Ponty, and Gilles Deleuze, as well as on interdisciplinary studies in neuroscience and psychosomatic phenomena such as synesthesia. ${ }^{14}$ Merleau-Ponty suggested that embodied vision should be seen 'not as a chunk of space or a bundle of functions but that body which is an intertwining of vision and movement' (2007: 353), thus posing challenges to any simplified conception of the relationship between vision and the embodied instruments of our senses. In cinematic contexts, Sobchack argues that through its employment of 'modes of embodied existence', cinema might be seen not as a medium that merely reflects or reinvents lived experience, but as a co-extension of experience, engaging with subjectivity through 'common structures of embodied existence, through similar modes of being-in-the-world' (1992: 5). Cinema can open up the singular and embodied world of the senses to a collective audience, making individual experience 'accessible and visible to more than a single consciousness who lives it' (Sobchack 1992: 9).

Gathering up these threads of private body, shared experience, and exhibition (tending towards hypervisibility), new queer documentaries can be situated within the dynamics Ken Plummer has characterised as new formations of 'intimate citizenship.' In Plummer's words, this is a 'sensitising concept which sets about analysing a plurality of public discourses and stories about how to live the personal life in a late modern world where we are confronted by an escalating series of choices and difficulties around intimacies' (2001: 238). Importantly, and reminding us of documentary's role in the production of contested public space, intimate citizenship is also about what Plummer calls 'arenas of intimacies' - the public display and representation of personal relations, genders, eroticisms, and so on, summing up emerging forms of life and cultures that Anthony Giddens referred to as the postmodernization of intimacies (Giddens 1992: 113-14). Here, Plummer suggests, 
the demands of public citizenship intersect and can collide with exploring and understanding one's own body, with relating to the world as a gendered being, with being an erotic or sexual subject.

Queer documentaries of NQC's first wave were, at a critical political juncture, magnifying relations between bodies on screen and sensory perception while retaining an awareness of documentary's potential as public utterance, throwing light on the contested and often painful intersections between private and public space, the body as personal experience and as political struggle and intervention. As Riggs stated in an interview about Tongues Untied: 'I wanted to show how people touch, and the touching. I didn't want to show pornography. I wasn't interested in showing erect genitalia and so forth [...] I wanted to show two black men touching tenderly, romantically, sexually [...] an image that I had never seen and which would confirm an experience for a number of other people' (qtd in Bullert 1997: 98). Riggs's emphasis on correspondences between 'showing' and 'touching' is often radically enacted in these documentaries.

\section{Intimacy and embodiment}

Underscoring a heightened self-awareness of body politics in the urgency, anger, and overlapping sense of fragility and collective empowerment marking AIDS activism and queer cinema, Monica Pearl has contended that 'New Queer Cinema is AIDS cinema' (2004: 23, italics in original). A documentary that powerfully explores both imbrications and 'catastrophic disruptions' (2004: 34) of the private and social body is Silverlake Life: The View from Here (1992), made by Tom Joslin with his partner Mark Massi and completed by their friend Peter Friedman. While less selfevidently stylised, it shares Hammer's aims of highlighting suppressed and historically elided queer experience, working to politicise the private and subcultural through making palpable the liminal relations between consciousness and the body (Lane 2002: 88). In many respects this experiment in autoethnography (Pratt 1991; Muñoz 1995) cuts through observational and objective lineages in documentary, drawing on the video diary approach in foregrounding documentary's potential as an 'act of bearing witness' - both externally seeing and experiencing from within (Hallas 2009: 16).

Nichols places Silverlake Life along with Tongues Untied within the rhetorical category of direct address documentary, in which 'I or We speak about us to you' 
(Nichols 2001: 18). As personal testimony, the text does enact a displacement of the seemingly neutral 'we' of documentary tradition towards asserting a speaking 'I', though it makes tangible both media interference and immediacy in its visual and auditory choreographies and physically wrenching evocations of living with illness, ultimately engaging with the endpoint of bodily sentience, death, defying taboos of recording and screening this process. It employs techniques, like Hammer, of formal layering, here the layering unfolding through complex interpersonal and mediated exchanges, screened via a style and form that Hallas refers to as a mise-en-abyme of video camera and televisual screen set-ups (2009: 125). These techniques draw the filmgoer into an over-layering of consciousness, emotion, physical intensity, and memory (the latter often visibly and painfully marked as virtual, underscoring how memory work paradoxically can be an evocation both of immediacy and absence).

For Hallas, the potent combination of domestic setting, camera exchanges which perform a 'shared textual authority', and Tom's and Mark's affecting personal interactions and looks into the camera (and at video footage, in communication with each other) combine to produce an immersive sensation of being 'sutured into the video's reciprocal rhythm, folded in intimate exchange' (2009: 123). The filmgoer's own body and senses are touched and enveloped by this ongoing candour and reciprocity. Silverlake Life hence bridges presumed distances embedded within the physical, spatial, and temporal dimensions of memory and mediation, as the intercutting of Joslin's earlier Blackstar helps to drive home (figure 4). As Henri Bergson suggested in Matter and Memory, 'there is no perception which is not full of memories. With the immediate and present data of our senses we mingle a thousand details out of our past experience.' Perception in the present is, Bergson argues, 'impregnated with our past' (1988: 2). 

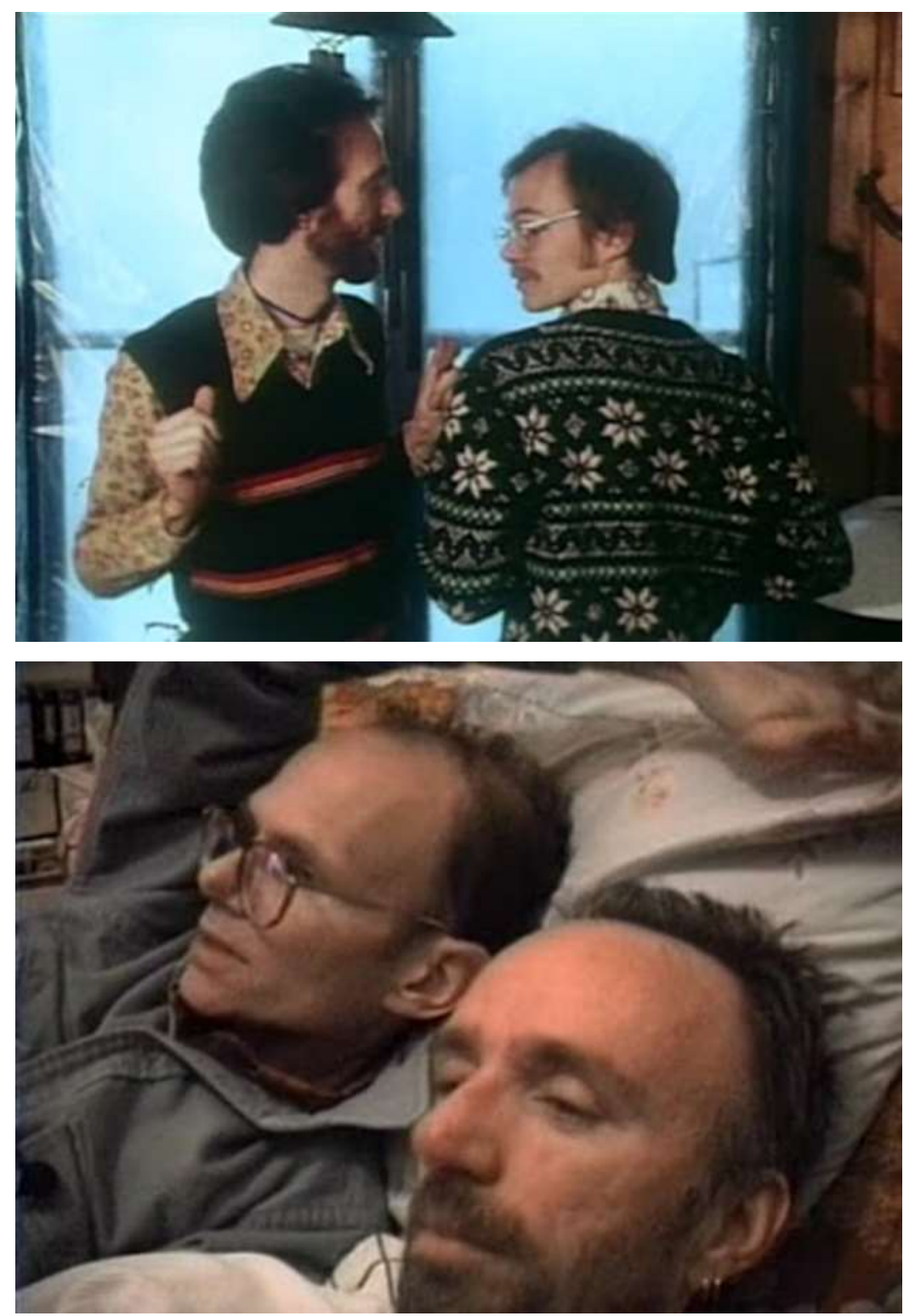

Figure 4: Silverlake Life: The View from Here (Tom Joslin, Mark Massi, and Peter Friedman, 1992)

The opening scene is significant, evoking in the present tense someone who can no longer be physically touched or held. The sequence is dominated by stark reminders of absence: Mark speaks while fidgeting with a polaroid of Tom, followed by a lingering close-up of ashes in an urn, performing a hysteron proteron, or 'preempting the end at the beginning' (Hallas 2009: 127). Yet Silverlake Life addresses the audience as imagined presence, while Mark's words at the same time conjure up the feel and textures of another living body. It thus begins by troubling any neat dichotomy of absence and presence, distance and embodiment: reaching out to the filmgoer's desire and inability to touch bodies on screen by summoning a memory of sharing touch with a sentient body now absent. The first words recall Tom through 
sense memory: 'The thing I remember most about Tom', Mark says, 'is what he feels like.' He continues, 'I know what his neck feels like, to kiss and bite it, and I know what his head feels like . . . his forehead. I u sed to be able to just run into the other room and kiss him on the forehead, or pester him or get some attention from him, and I can't do that anymore.' The use of the present tense here is telling; it goes against reason, evidence, factuality — death as past tense, the opposite of life-yet many people watching might share in this sensation in their own experience. Mark's words begin to collapse distinctions between Tom's body as felt and as mediated presence (and a close-up of Tom appears on a video monitor, addressed to Mark, saying 'I love you'), while the montage (the lingering image of ashes) testifies to the absence of consciousness, sense, and the body after death.

Only after meditating on touch does Mark consider the visual image of Tom, through a tender and self-aware description (which recalls Mark's acute selfawareness in Blackstar) of looking at Tom's body immediately after death. Glancing at the polaroid he holds in his hand, Mark says,

It was very scary to look at him, the first time after he died, to look him in the face. But I did. [...] And then I wanted to close his eyes, because it's very strange to see a dead person staring, and I tried just like in the movies to close the eyelid. It doesn't close-it pops back open. As I said to Tom, I apologize, life wasn't like the movies. In the movies you just so dramatically close the eyelids and it's all over with. But, it didn't.

In this way Silverlake Life and Mark relay the intimate connection between traumatic experience and the everyday, while also suggesting how intimacy can powerfully inhere within a virtual construct. Mark's words both assert the gap ('life wasn't like the movies') between notions of intimacy as the proximity of bodies in shared space and intimacy as a virtual experience, and they collapse that gap, drawing on virtual technology as a shared medium for bearing witness. Shaka McGlotten suggests this enfolding of intimacy into the virtual: 'intimacy is supported by a range of discourses and practices, but as an experience it is composed largely of feelings, feelings more or less connected, as if one belongs or doesn't. In this way, intimacy is and always has been virtual. [...] virtuality is one way to conceptualize intimacy's ongoing immanence' (2013: 9). Our connection to the lives of Mark and Tom is thus marked at once as both virtual and material, we are displaced yet also emotionally and physically, palpably, intertwined. 
Returning us to Laura Marks's exploration of touch and haptic visuality, Matt Brennan (2011) situates Silverlake Life alongside films and videos contemplating illness, aging, bodily wasting, and death, underscoring how they can allow us 'to come physically close to illness, to feel it within', and how this process might viscerally threaten the filmgoer's sense of their own whole or integrated body. The film 'presses us up against the bodies depicted, and our own feelings of bodily threat seem not unlike a transmission of illness from subject to spectator, engendering not only pity but also, and more powerfully, a kind of empathy' (2011). Such films and videos bring about bodily discomfort and also provoke intense connection between the skin of the body and the skin of film — bringing vividly into being the fragility of our own bodies and our lack of immunity to illness and death, moreover making us 'cognizant of the fact that a failure to change can be as deleterious to our own health as to that of the subject. We cannot help but be changed by such an interaction with the film text' (2011, italics in original). This stress on change points to how such intense moments of connection between the body in documentary and the body of the filmgoer might work to reconnect cinema experience to world experience, to an ethics of social change.

\section{Gesture and touch}

Much phenomenological engagement with cinema as intimate, sensory, and tactile experience has more recently converged around the fundamental yet still underexamined status of cinematic gesture. Attention to the gestural has often featured in analysis of documentary performance (Nichols 1994: 72; Waugh 2000 [1996]: 260). Yet the fleeting motions and micro-movements of bodies on screen, such as Mark Massey's slight hand gestures as he describes efforts to close Tom's eye-although usually figured as marginal in terms of both visual and narrative importance-can further shift the emphasis on the visual, photographic, and storytelling elements of cinema towards considerations of how gesture in cinema can effectuate forms of intimacy and touch. Such a potential in gestures to signify and manifest touch has been explored by Thomas Elsaesser, even while being heedful of the risk of 'becoming yet another ideology of pre-symbolic fusion, a golden age or paradise lost of immediacy and authenticity' (2014: 23). A growing interest in cinema gesture and its resistance to reductive analysis (Harbord 2014; Stewart 2014; Chare and Watkins 
2017) has focused around the work of Giorgio Agamben, who expanded on Deleuze's 'movement image' in foregrounding the distinctive qualities of cinematic gesture.

In 'Notes on Gesture' (2000: 48-59) Agamben argues that, 'the element of cinema is gesture and not image' (2000: 54, italics in original). Thinking more profoundly about gesture, then, helps to free movement in cinema from a teleological understanding of an endpoint or purpose (such as: a running figure is necessarily running towards something, acting as a sign that points towards an end and embedded in a complete movement). Narrative cinema further tends to subsume the gesture and its potentiality within a broader web of intentionality; as Hampus Hagman puts it, in these cases the gesture becomes 'goal-oriented and causal in nature' (Hagman 2012). Gestures as marked by the moving image can, in Agamben's view, be decoupled from interpretive frameworks that demand more narrowly defined signifying ends. Cinematic gesture might instead be conceived as what Agamben calls 'the exhibition of a mediality' (2000: 57, italics in original) - that is, media in motion, both within and ephemerally holding on to the motion, indicating a process rather than providing a reducible result or thing. Agamben sees a goal-oriented humanity that has lost awareness of the gestural, where instead 'each single gesture becomes a destiny' (2000: 52). We might recall here modern industrial drives to manage and subsume the gesture, such as Frank and Lillian Gilbreth's photographic and cinematographic experiments for overseeing efficiencies in factory workers' movements (figure 5). As Frank Gilbreth argued: 'There is no waste of any kind in the world that equals the 
waste from needless, ill-directed, and ineffective motions' (qtd in Cresswell 2006: 98)

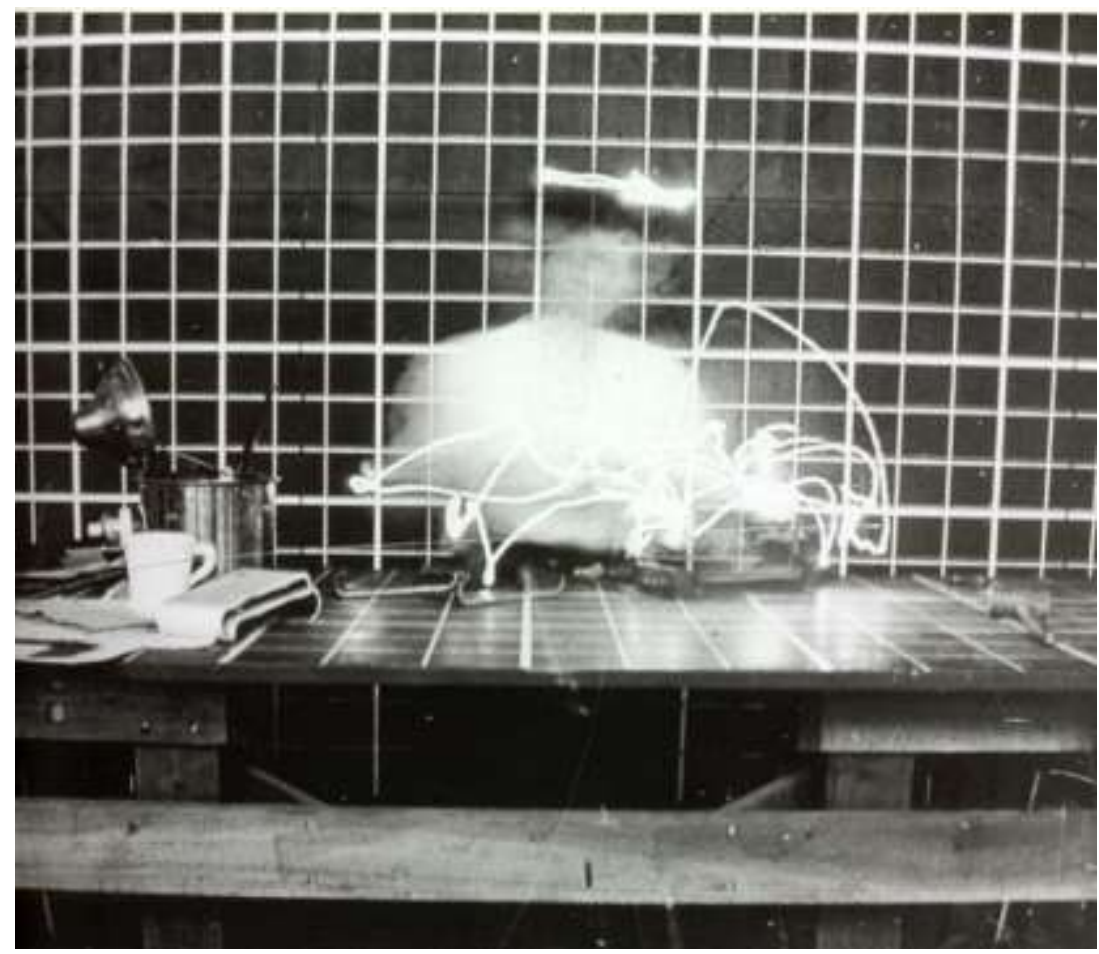

Figure 5: Frank and Lillian Gilbreth: Time and motion efficiency study

Agamben's reading further recalls pre-cinematic nonfiction, especially the chronophotography of Eadweard Muybridge and Etienne-Jules Marey, where the (pre-)cinematic held the promise of a technology that could aid in scientific progress, yet at the same time was recording traces of what escaped the goal of the experiment, effectively revealing ghosts of gestures that modern commerce and industry were attempting to efface. Cinema technology thus fleetingly points to those gestural subtleties that Agamben refers to as breaking with 'the false alternative between ends and means'- exploring means without ends (2000: 56). Much new queer documentary draws on cinema technology to heighten attention to the gestural so often suppressed in everyday modern life, and cinema, to articulate the intermediacies of movement, which for Agamben signals a release from teleological impulses towards commodification and epistephilia. We might get a sense here of the de-essentialising moves of much queer documentary, for example Hammer's Double Strength (1978) and Synch Touch (1981), where 'erotic vocabularies are respectively balletic and gestural [...] "performed" intimately to the camera' (Waugh 1997: 260).

Tongues Untied, 'possibly the most powerful examination of black sexual identity ever produced' (Jones 1993: 256), creates a mosaic of African 
American/male/queer identity through painstaking visual (framing, blocking, lighting, closeness and depth) and acoustic (music, poetry, episodic narrative, testimony) evocations of embodied subjectivity and the body's gestural subtleties (figure 6). Early in the video, suggesting baptism and ritual transformation, Riggs uncloaks his body, slowing down movement and revealing the body's intermediate, suspended physical utterances, hastening a haptic experience where key light conjures surface textures of skin and hair against the depths of black space. Riggs's choreography and cinematic style elicits perceptions of the body as performative but also sentient: contested public territory and sensual private experience. His voiceover and movements are assured and fluid, yet the body's very exposure on camera and its fraught poses render sensible the exposure of LGBTQ people and people of colour to a predominantly hostile public and media gaze.

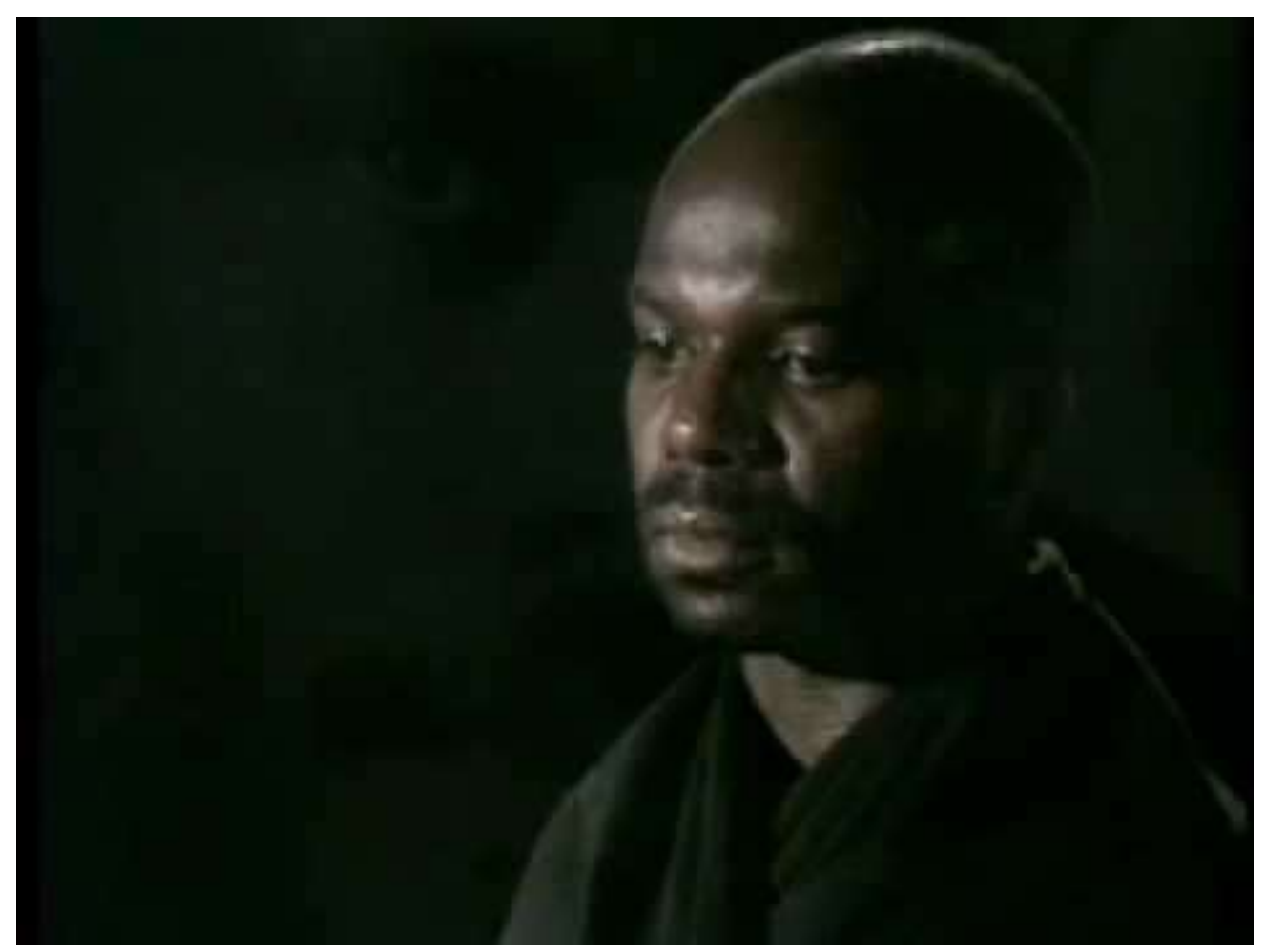

Figure 6: Tongues Untied (Marlon Riggs, 1989)

The emphasis on gesture also points to what is not patently fact based or consumable, where gesture's mediality might be seen to occupy a space where narrative, explanatory devices, or other forms of 'official' discourse no longer suffice in producing meaning and knowledge. We are touched by a body (like all bodies) in transition, moving towards the un-representable and unknowable, a process into which the filmgoer is drawn. A heartbeat drumming beneath this early scene hints at 
this odyssey, a peripatetic and transformational journey, underscored by Riggs's revelation of his HIV-positive status. It is worth noting as well that videotape is itself a transitional and transient medium, tracing and screening gesture while also occupying a kind of boundary status: an analogue form that served as an early medium for encoding digital data. And while videotape was for Riggs a low-budget necessity, it is not treated as a constraint; the medium is manipulated and rendered with exquisite clarity, its reputation for lo-fi visuals (as opposed to the 'sheen' of celluloid) honed into a new aesthetic. These processes and ongoing means (without ends) of audiovisual media are accentuated and lingered over in Tongues Untied.

Riggs, Essex Hemphill, and their collaborators underline the mobility of gesture and meaning though variously structured and unstructured expressive elements such as rhythmic, free-form dance and poetry, all of which accent the importance of a creative, fluid stance in tracing what has been lost or remains vestigial in expressions of black, LGBTQ, intersectional lives. Alex Castro suggests that the scenes of vogue dancing, for example, assert 'a form of resistance and community' (Castro 2000). The vogue dance also, like Riggs's self-presentation and hybrid stylistic approach throughout, resists pinning down or securing specific interpretations; dance, poetry, and cinema are art forms that might be seen to deny human desires towards progressive outcomes and definitive meanings; they 'trace a magic circle in which humanity' might evoke what is 'slipping through its fingers forever' (2000: 53). Techniques such as the persistent slow- and stop-motion lingering in Tongues Untied trace and give fleeting substance to cinematic gesture, which in Agamben's terms is perceivable but never fully grasped-a ghost or memento of human transience. For Agamben this apprehension also suggests an ethical dimension (2000: 57) which suspends cinema and its gestures from commodified ends and encourages what I would call a more rhizomatic than arborescent (or hierarchical) mode of acquiring understanding. Riggs has produced forms of truth and knowledge, though not truth based in primarily asserting facts and advancing a logical argument, nor knowledge imparted via didactic means. Nor is this the 'Rashomon effect' of truths and epistemologies that emerge out of conflicting accounts and points of view (Kakutani 2018: 18). This is a politics of truth emerging out of the mediated spaces of transitory perception, memory, the body, senses, and attention to gesture: what tends to slip past authoritative processes of showing and telling modern experiences of the world. 
Embedding his own body and voice in a text that persistently evokes the haptic and polyvocal, Riggs refuses to explicate any unified 'truth' of black LGBTQ life and instead triggers a felt presence, situating his own sentient body within a complex world of hostility and violence, and also of sensation, desire, humour, and pleasure, encouraging audiences to participate in these interlocking spheres of experience while pointing towards new forms of personal and political engagement with the documentary form. Marked by over-layerings of image and sound, the video tends to impart impressions rather than offering definitive factual statements and consumable information. The hypnotic, fraught gestures of Riggs's body against black space, the dazzling fade to white after the opening montage, the forays into dance and rhythmic poetry: each leaves a transitory physical impression—visual, auditory, kinaesthetic felt traces.

\section{Engaging magnitude}

Such felt traces lie at the heart of the liminal and affective realms of intimacy, embodied subjectivity, and gesture in cinema. The challenge of further connecting these felt traces to actual experience of the world is often palpable in these new queer documentaries, emblematized in a term that has occupied a relatively unassuming but key role in discussions of documentary's status and functions over the yearsmagnitude. Explored extensively by Nichols in 'Representing the Body: Questions of Meaning and Magnitude' (1991: 229-66), the concept has only infrequently been named and elaborated on outside of Nichols's work. ${ }^{15}$

Relating documentary's potential impact to questions of magnitude, Leshu Torchin recently wrote about chairing a session at the Edinburgh Film Festival which addressed challenges that documentaries face in an era of rapidly increasing consumption of nonfiction media across different platforms, at a time when many mainstream political figures and pundits are dismissing media's factual claims. Recent years have seen a shift away from storytelling as documentary's chief selling point towards so-called content marketing, which means that clips or fragments from longer-form works are shared and 'liked' on social media-a practice that has become standard among funders and broadcasters (Torchin 2017). These bites have their uses, Torchin argues, but it is not clear if this kind of social media activity is translating into more complex engagement with the media content, its broader implications, or with the longer format documentaries themselves. 
Documentaries traditionally have laboured to 'make sense' of complex ideas, histories, and experiences by offering narrative coherence and interpretation; they have pointed towards solutions or indicated actions we might take to address the practices, social elisions, dilemmas, and global/local crises they reveal. In this respect, thinking about magnitude in terms of documentary's explanatory functions would seem to bear an uncomfortable relation to gesture as explored via Agamben, above, as the power of the cinematic gesture appears to lie, in Agamben's conceptualisation, outside of realms of generating specific endpoints, conclusions, and narrative purpose. But documentaries, and this is true of new queer films and videos explored here, can also mark the impossibility of desires for fuller explanation or completion, gesturing towards unknown and ambivalent horizons of experience even while advancing a politics of social change and intervention. They can, as Nichols argues, engage an 'awareness of the tension between representation and [...] magnitudes beyond representation', through perceptions of 'direct encounter and physical presence' that then take on 'experiential meaning' (1991: 233, italics in original).

A profound meditation on this dialectical relation between physical presence and meaning, between representation and what lies beyond, can be found in Derek Jarman's autobiographical Blue (1993), which asserts magnitudes beyond representation in part through its unconventional retreat from the live-action image while foregrounding the vagaries of colour perception and acoustic space, gesturing towards magnitudes (the sublime, illness, AIDS, time's passage, social moralising and shaming, death) beyond the frame through a 'corporeal implication', as Hallas puts it, that constructs 'a different kind of intersubjective space that implicates the spectator's own body in the process of bearing witness' (Hallas 2009: 33). Nitrate Kisses also uses sound and the spoken word to evoke magnitudes beyond the frame, as contrapuntal accompaniments to the visual layers and juxtapositions that together work to make felt the queer body absent from history and the archive. Silverlake Life, as suggested above, evokes a physical closeness and intensity while interweaving direct address, exchange, and reciprocation, drawing on montage effects where the present bleeds into the past and past into present, disturbing presumed dichotomies of bodily tactility and absence, direct and mediated experience.

Tongues Untied further explores strategies of corporeal implication that underline the affective impact of audiovisual media, palpably connecting this experience to broader social networks, ecologies, and an urgent need for change. In a 
tender love scene near the end, the camera lingers over and frames the bodies' gentle movements and textures, images underscored by a heartbeat rhythm that simultaneously registers both vitality, and mortality. This heartbeat punctuates the video, at times as a marker of life and sentience, at others evoking what Riggs calls 'a time bomb ticking in my blood' (Wallenberg 2004: 139). This sense of mortality comes through strongly in the following sequence, where a photo of Riggs appears among black men that have died, including the writer, editor, and activist Joseph Beam, James McLaurin, and other activists, artists, authors, drag performers: a crowd of faces fills the screen. Riggs speeds up the montage until the image freezes on a photo of his own face, isolated and in silence (we are hardly aware of the ceasing of the heartbeat). Robert LeBlanc indicates ways in which these physically involving techniques point towards magnitude, noting Riggs's focus on silence and absence as counterparts to presence, and how this gestures towards the margins or out-of-frame. Rather than further 'an imaginable moment of "completion" of the documentary's goal', absence and silence serve to posit, 'an ultimate unrepresentability of certain events and subject positions' restricted by social expectations and responses (LeBlanc 2009: 2).

Riggs had been diagnosed HIV-positive in December 1988, part of the way through taping what he had planned to be a short video shown only to gay audiences. Riggs nonetheless refuses to adopt a victim status, and the sound of the heartbeat resumes again as he calls up a history of Civil Rights resistance and advocacy, dissolving these scenes into images of a gay pride demonstration (featuring marchers for MTFA, the Minority Task Force on AIDS). Opening out from a stress on autobiographical and subcultural testimony, Tongues Untied becomes polyvocal as it links to diverse sites and histories of resilience and activism, signalling where the personal body meets the political and the world at large, intimating the struggles that have come before and that still lie beyond the filmic realm, from the everyday encounter to the halls of Congress. Rhea Combs has aptly referred to Riggs's processes of 'exceeding the frame' (Combs 2009), and this kind of dialectical move (between private/public, inside/outside, containment/excess, filmic/extra-filmic), found across much new queer documentary work, might be seen as gesturing towards magnitudes — which, as Nichols suggests, are not always imparted through cause and effect or narrative means. Magnitude 'involves a tension between the representation 
and the represented as experienced by the viewer' (Nichols 1991: 232, italics in original).

Though we consume and respond in diverse ways to mediated sounds and images of the world, commonly served up as shared, and liked, bites of information, we do not necessarily feel or comprehend their magnitudes. As the public comments sections beneath internet sites uploading and streaming video capture of traumatic events and tragedies reveal, exposure to what others have witnessed and experienced does not necessarily add to one's knowledge. Though we might engage in an intense, visceral virtual experience of reality, still that representation must be registered as something felt, lived through, connected to experiences and ecologies of the world. For Nichols, 'the magnitudes opened up by a text are not merely a matter of naming something of profound importance', beyond this, filmgoers need to be situated and involved with 'subjective intensity' (1991: 232).

We might develop an awareness of magnitude through an awareness of a tension, as I think we find in films and videos explored here, between what is represented, one's embodied experience of the world, and what the representation implies or signals: a multi-layered process that therefore 'involve[s] a different order of engagement. The terms remain emotional, experiential, visceral' (1991: 234). Linking the sensate self to the world means perceiving the singular body within the social and ecological body in which it is imbricated and constituted-one's body 'must then be viewed as an ensemble of socio-ecological relations' (Harvey 2000: 236). This is where documentary can come in: intimately drawing the personal and potentially embodied nature of the cinema experience towards magnitudes beyond the screen. This task might be considered an ever-receding horizon of attainment which continues to give impetus to documentary as an endeavour, public utterance, and as personal and social experience. ${ }^{16}$

\section{Works Cited}

Agamben, Giorgio ([1993] 2000). 'Notes on Gesture.' Means without Ends: Notes on Politics. Trans. Vincenzo Binetti and Cesare Casarino. Minneapolis: University of Minnesota Press. 42-60.

Alter, Nora M., and Timothy Corrigan, eds. (2017). Essays on the Essay Film. New York: Columbia University Press.

Barker, Jennifer (2009). The Tactile Eye: Touch and the Cinematic Experience. Berkeley: University of California Press. 
Bergson, Henri ([1911] 1988). Matter and Memory. Trans. Nancy Margaret Paul and W. Scott Palmer. New York: Zone Books.

Berlant, Lauren (1998). 'Introduction' to 'Intimacy: A Special Issue.' Critical Inquiry 24.2 (Winter): 281-88.

Beugnet, Martine (2007). Cinema and Sensation: French Film and the Art of Transgression. Edinburgh: Edinburgh University Press.

Brasell, R. Bruce (2015). The Possible South: Documentary Film and the Limitations of Bi-raciality. Jackson: University Press of Mississippi.

Brennan, Matt. 'Bodies Politic/Body Politics: The Political and the Personal in Contemporary Film Essays.' Bright Lights Film Journal. 31 July 2011. https://brightlightsfilm.com/bodies-politicbody-politics-the-political-and-thepersonal-in-contemporary-film-essays/\#.XPVNzxZKjIU.

Brett, Oliver (2013). The lieu factice: Performance, Identity, and Place in French and Italian Queer Documentary since 2000. PhD dissertation, University of Leicester, UK.

Bruno, Giuliana (2002). Atlas of Emotion: Journeys in Art, Architecture, and Film. New York: Verso.

Bui, Camille (2014). 'Tongues Untied (Marlon Riggs, 1989) et Paris is Burning (Jennie Livingston, 1990): les documentaires du New Queer Cinema.' Revue LISA/LISA e-journal: Littératures, Histoire des Idées, Images, Sociétés du Monde Anglophone. 12.1. https://journals.openedition.org/lisa/8513.

Bullert, B J. (1997). Public Television: Politics and the Battle Over Documentary Film. New Brunswick, NJ: Rutgers University Press.

Bullert, B. J. (1994). 'Anatomy of a Controversy: Public Television and the Dark Circle Case.' Wide Angle 16.1-2 (August): 6-39.

Butler, Cornelia, and Alexandra Schwartz, eds (2010). 'Modern Women: Barbara Hammer on Maya Deren.' The Museum of Modern Art (MOMA, New York) and Plowshares Media. Video interview. http://www.moma.org/modernwomen.

Castro, Alex (2000). 'Tongues Untied.' Senses of Cinema 6 (May). http://archive.sensesofcinema.com/contents/cteq/00/6/tongues.html.

Chanan, Michael (2007). The Politics of Documentary. London: British Film Institute.

Chare, Nicholas, and Liz Watkins, eds. (2017). Gesture and Film: Signalling New Critical Perspectives. London: Routledge.

Combs, Rhea (2009). Exceeding the Frame: Documentary Filmmaker Marlon T. Riggs as Cultural Agitator. PhD dissertation, Emory University. https://search.proquest.com/openview/3120ade105d7900b081e6dfcde3f2ec2/1 ?pq-origsite $=$ gscholar $\& \mathrm{cbl}=18750 \&$ diss $=\mathrm{y}$.

Corner, John (2002). 'Documentary in a Post-Documentary Culture? A Note on Forms and Their Functions.' www.lboro.ac.uk/research/changing.media/John\%20Corner\%20paper.htm.

Corrigan, Timothy (2011). The Essay Film: from Montaigne, after Marker. New York: Oxford University Press.

Crenshaw, Kimberlé Williams (1994). 'Mapping the Margins: Intersectionality, Identity Politics, and Violence Against Women of Color.' The Public Nature of Private Violence. Ed. Martha Albertson Fineman and Rixanne Mykitiuk. New York: Routledge. 93-118.

Crimp, Douglas (2002). Melancholia and Moralism: Essays on AIDS and Queer Politics. Cambridge, MA: The MIT Press. 
Cvetkovich, Ann (2002). 'In the Archives of Lesbian Feeling: Documentary and Popular Culture.' Camera Obscura 17.1: 107-47.

Cytowic, Richard E. (1989). Synesthesia: A Union of the Senses. New York: SpringerVerlag.

De Lauretis, Teresa (1991). 'Queer Theory: Lesbian and Gay Sexualities.' differences: A Journal of Feminist Cultural Studies 3.2: iii-xviii.

Deleuze, Gilles (1986). Cinema 1: The Movement Image. Minneapolis: University of Minnesota Press.

Dittmar, Linda (1997). 'Of Hags and Crones: Reclaiming Lesbian Desire for the Trouble Zone of Aging.' Between the Sheets, In the Streets: Queer, Lesbian, Gay Documentary. Ed. Chris Holmlund and Cynthia Fuchs. Minneapolis: University of Minnesota Press. 71-90.

Dyer, Richard, with Julianne Pidduck (2003 [1990]). Now You See It: Studies in Lesbian and Gay Film. London: Routledge.

Elsaesser, Thomas (2014). 'Touch and Gesture, on the Borders of Intimacy.' Intimacy in Cinema: Critical Essays on English Language Films. Ed. David Roche and Isabelle Schmitt-Pitiot. Jefferson, NC: McFarland. 17-33.

Geiger, Jeffrey (2011). American Documentary Film: Projecting the Nation. Edinburgh: Edinburgh University Press.

Gever, Martha, Pratibha Parmar, and John Greyson, eds (1993). Queer Looks: Perspectives on Lesbian and Gay Film and Video. New York: Routledge.

Giddens, Anthony (1992). The Transformation of Intimacy: Sexuality, Love and Eroticism in Modern Societies. Cambridge: Polity.

Guenette, Robert (1987). 'Oscar Winning Documentaries: Attention Must Be Paid.' The Hollywood Reporter, 17 March: S26-S28.

Hagman, Hampus (2012). 'The Digital Gesture: Rediscovering Cinematic Movement through GIFs.' Refractory: Journal of Entertainment Media (29 December). http://refractory.unimelb.edu.au/tag/agamben/.

Hallas, Roger (2009). Reframing Bodies: AIDS, Bearing Witness, and the Queer Moving Image. Durham, NC: Duke University Press.

Hammer, Barbara (1993). 'The Politics of Abstraction.' Queer Looks: Perspectives on Lesbian and Gay Film and Video. Ed. Martha Gever, Pratibha Parmar, and John Greyson. New York: Routledge. 70-75

Hammer, Barbara (2008). 'Shaking the Archive.' Barbarahammer.com. http://barbarahammer.com/wpcontent/uploads/2015/01/Shaking_The_Archive.pdf.

Harbord, Janet (2014). 'Gesture, Time, Movement: David Claerbout meets Giorgio Agamben on the Boulevard du Temple.' Cinema and Agamben: Ethics, Biopolitics, and the Moving Image. Ed. Henrik Gustafsson and Asbjørn Grønstad. London: Bloomsbury. 71-88.

Harvey, David (2000). Spaces of Hope. Edinburgh: Edinburgh University Press. Hight, Craig (2010). Television Mockumentary: Reflexivity, Satire and a Call to Play. Manchester: Manchester University Press.

hooks, bell (1992). Black Looks: Race and Representation. Boston: South End Press. Howes, David (2006).'Charting the Sensorial Revolution.' The Senses and Society 1.1: 113-28.

Howes, David (2013). 'The Expanding Field of Sensory Studies.' Sensorystudies.org. https://www.sensorystudies.org/sensorial-investigations/the-expanding-fieldof-sensory-studies/. 
Jones, Jacquie (1993). 'The Construction of Black Sexuality.' Black American Cinema. Ed. Manthia Diawara. New York: Routledge. 247-56.

Juhasz, Alexandra (1995). AIDS TV: Identity, Community, and Alternative Video. Durham, NC: Duke University Press.

Juhasz, Alexandra (2008). 'Documentary on YouTube: The Failure of the Direct Cinema of the Slogan.' Rethinking Documentary: New Perspectives, New Practices. Ed. Thomas Austin and Wilma de Jong. Maidenhead, UK: Open University Press. 299-312.

Kakutani, Michiko (2018). The Death of Truth: Notes on Falsehood in the Age of Trump. New York: Tim Duggan Books.

Lane, Jim (2002). The Autobiographical Documentary in America. Madison: University of Wisconsin Press.

LeBlanc, Robert (2009). 'Representing Postmodernity and Marginality in Three Documentary Films.' Comparative Literature and Culture 11.2 (June): 1-10. http://docs.lib.purdue.edu/clcweb/vol11/iss2/12.

MacDonald, Myra (2002). 'Politicizing the Personal: Women's Voices in British Television Documentaries.' News, Gender and Power. Ed. Cynthia Carter, Gill Branston, and Stuart Allen. London: Routledge. 117-132.

MacDougall, David (2006). The Corporeal Image: Film, Ethnography, and the Senses. Princeton, NJ: Princeton University Press.

Marks, Laura U. (2000). The Skin of Film: Intercultural Cinema, Embodiment, and the Senses. Durham, NC: Duke University Press.

Marks, Laura U. (2002). Touch: Sensuous Theory and Multisensory Media. Minneapolis: University of Minnesota Press.

McGlotten, Shaka (2013). Virtual Intimacies: Media, Affect, and Queer Sociality. Albany: SUNY Press.

Mellor, Felicity (2009). 'The Politics of Accuracy in Judging Global Warming Films.' Environmental Communication 3.2: 134-150.

Mercer, Kobena ([1991] 1993). 'Looking for Trouble.' The Lesbian and Gay Studies Reader. Ed. Henry Abelove, Michele Aina Barale, and David M. Halperin. New York: Routledge. 350-59.

Merleau-Ponty, Maurice ([1964] 2007). 'Eye and Mind.' The Merleau-Ponty Reader. Ed. Ted Toadvine and Leonard Lawlor. Evanston: Northwest University Press. 351-78.

Muñoz, J. (1995). 'The Autoethnographic Performance: Reading Richard Fung's Queer Hybridity.' Screen 36.2: 83-99.

Nichols, Bill (1991). Representing Reality: Issues and Concepts in Documentary. Bloomington: Indiana University Press.

Nichols, Bill (1994). Blurred Boundaries: Questions of Meaning in Contemporary Culture. Bloomington: Indiana University Press.

Nichols, Bill (2001). Introduction to Documentary. Bloomington: Indiana University Press.

Pearl, Monica (2004). 'AIDS and New Queer Cinema.' New Queer Cinema: A Critical Reader. Ed. Michele Aaron. Edinburgh: Edinburgh University Press. 23-35.

Pidduck, Julianne (2004). 'New Queer Cinema and Experimental Video.' New Queer Cinema: A Critical Reader. Ed. Michele Aaron. Edinburgh: Edinburgh University Press. 80-97. 
Pidduck, Julianne (2006). 'New Queer Documentary and the "Substances" of Queer Kinship.' Paper presented at the annual meeting of the American Studies Association. http://citation.allacademic.com/meta/p114620_index.html

Pidduck, Julianne (2011). 'The Visible and the Sayable: The Moment and Conditions of Hypervisibility. Cinematic Queerness: Gay and Lesbian Hypervisibility in Contemporary Francophone Feature Films. Ed. Florian Grandena and Cristina Johnston. Oxford: Peter Lang. 9-40.

Plantinga, Carl (2009). 'Documentary.' The Routledge Companion to Philosophy and Film. Ed. Paisley Livingston and Carl R. Plantinga. London: Routledge. 494504.

Plummer, Ken (2001). 'The Square of Intimate Citizenship.' Citizenship Studies 5.6 (November): 237-255.

Pratt, Mary Louise (1991). "Arts of the Contact Zone." Profession (Modern Language Association): 33-40.

Queer Nation (1990). 'Queer Nation Manifesto.' Broadsheet handout. http://www.historyisaweapon.com/defcon1/queernation.html.

Raimondo, Meredith (2010). 'The Queer Intimacy of Global Vision: Documentary Practice and the AIDS Pandemic.' Environment and Planning D: Society and Space 28.1: 112-127.

Renov, Michael (2004). The Subject of Documentary. Minneapolis: University of Minnesota Press.

Rich, B. Ruby (1992). 'New Queer Cinema.' Sight and Sound 2.5 (September): 30-34. https://www.bfi.org.uk/news-opinion/sight-sound-magazine/features/newqueer-cinema-b-ruby-rich.

Rich, B. Ruby (2013). New Queer Cinema: The Director's Cut. Durham, NC: Duke University Press.

Roche, David, and Isabelle Schmitt-Pitiot, eds (2014). Intimacy in Cinema: Critical Essays on English Language Films. Jefferson, NC: McFarland.

Smaill, Belinda (2009). 'Documentary Investigations and the Female Porn Star.' Jump Cut: A Review of Contemporary Media 51. http://www.ejumpcut.org/archive/jc51.2009/femalePornstars/text.html.

Smith, Ralph R., and Russel R. Windes (2000). Progay / Antigay: The Rhetorical War over Sexuality. London: Sage.

Sobchack, Vivian (1992). The Address of the Eye: A Phenomenology of Film Experience. Princeton, NJ: Princeton University Press.

Sobchack, Vivian (2004). Carnal Thoughts: Embodiment and Moving Image Culture. Berkeley: University of California Press.

Stein, Ellin (1984). 'Leaner Times for Documentarians.' New York Times, 10 June: 25.

Stewart, Garrett (2014). 'Counterfactual, Potential, Virtual: Towards a Philosophical Cinematics.' Cinema and Agamben: Ethics, Biopolitics, and the Moving Image. Ed. Henrik Gustafsson and Asbjørn Grønstad. London: Bloomsbury. 161-190.

Stoller, Paul (1997). Sensuous Scholarship. Philadelphia: University of Pennsylvania Press.

Torchin, Leshu (2017). 'In the Era of Fake News, Honest Documentary Makers Have Never Mattered More.' The Conversation, 10 July. http://theconversation.com/in-era-of-fake-news-honest-documentary-makershave-never-mattered-more-80595. 
Villarejo, Amy (2005). 'Tarrying with the Normative: Queer Theory and Black History.' Social Text 23.3-4: 69-84.

Wallenberg, Louise (2004). 'New Black Queer Cinema.' New Queer Cinema: A

Critical Reader. Ed Michele Aaron. Edinburgh: Edinburgh University Press.

Waugh, Thomas (1992). 'Erotic Self-images in the Gay Male AIDS

Melodrama.' Fluid Exchanges: Artists and Critics in the AIDS Crisis. Ed.

James Miller. Toronto: University of Toronto Press. 122-34.

Waugh, Thomas (2000[1995]). 'We're Talking, Vulva, or, My Body is Not a

Metaphor.' The Fruit Machine: Twenty Years of Writings on Queer Cinema.

Foreword John Greyson. Durham, NC: Duke University Press. 237-45.

Waugh, Thomas (2000 [1996]). 'Walking on Tippy Toes: Lesbian and Gay Liberation

Documentary of the Post-Stonewall Period 1969-1984.' The Fruit Machine:

Twenty Years of Writings on Queer Cinema. Foreword John Greyson.

Durham, NC: Duke University Press. 246-70.

Williams, Linda (1989). 'Power, Pleasure, and Perversion: Sadomasochistic Film

Pornography.' Representations 27 (summer): 37-65.

Zimmermann, Patricia (2000). States of Emergency: Documentaries, Wars,

Democracies. Minneapolis: University of Minnesota Press.

\section{Notes}

${ }^{1}$ Rich herself expressed scepticism of an idealised, overarching characterisation of NQC, stressing for example that the 'queer new wave' was dominated by the 'boys on the block', while mainstream festivals often marginalised work by women and people of colour (Rich 1992).

${ }^{2}$ The term 'new queer documentary' has not been widely employed and these films and videos are usually invoked within the contexts of NQC. Oliver Brett defines 'new queer documentary cinema' by drawing on Rich's NQC and extending the concept to Italian and French queer documentary (Brett 2013:11 - 12). Julianne Pidduck used the term in a paper presented at the American Studies Association conference (Pidduck 2013); while Camille Bui looks in detail at strategies of resistance in Paris is Burning and Tongues Untied, framing the discussion with an examination of NQC's emergence (Bui 2014). Further with respect to terminology, a number of these films and videos are characterised as 'essay films', though there is little space to examine this overlap here. For considerations of these and related films (Riggs's Black Is, Black Ain't, Tongues Untied, Nitrate Kisses, Blue) in the context of the essay film, see Corrigan (2011: 207), Alter and Corrigan (2017: 170), Brennan (2011).

${ }^{3}$ It is worth keeping in frame Alexandra Juhasz's observation that much queer political documentary of the 1980s and early 1990s also drew on the inherited authority of documentary realist codes in seeking the 'validation of unconventional visions' (Juhasz 1995: 76).

${ }^{4}$ Intersectionality was named by Kimberlé Williams Crenshaw in the contexts of feminist, social, and legal theory (Crenshaw 1994).

${ }^{5}$ The term 'queer theory' is usually traced to a 1990 conference at Santa Cruz and a special issue of the journal differences based on the conference, edited by Teresa de Lauretis (de Lauretis 1991).

${ }^{6}$ As a critical tool, Amy Villarejo has convincingly argued for the ongoing potency of the term 'queer' when 'deployed as a catachresis, as a metaphor without an adequate referent', hence freeing the term from narrower, 'literal' definitions grounded in identity politics and sexual practices (Villarejo 2005: 70).

${ }^{7}$ Both The Thin Blue Line (1988) and Roger and Me (1989, the most financially successful feature documentary ever released at the time) were refused nominations by the Academy Awards committee. Concerns were cited about verifiability and accurate sequencing, meaning they did not qualify for the documentary category.

${ }^{8}$ On the New Right, the Culture Wars, and related controversies see Mercer (1993).

${ }^{9}$ Linda Dittmar refers to the film's emancipatory 'exuberance' but raises concerns that this approach might limit 'its erotic resonance as well as its intelligibility' (Dittmar 1997: 84).

${ }^{10}$ Earlier feminist documentary often focused on the body's entanglements in intense social pressures: the work of Liane Brandon (Anything You Want to Be [1971], and Betty Tells Her Story [1972]) highlighted the individual costs to women of patriarchal expectations. Works such as Margie Keller's 
Misconception (1978), about childbirth, and JoAnn Elam's Rape (1978) further denied patriarchal claims on the female body. Documentaries such as Marusia Bociurkiw's Bodies in Trouble (1991), dealing with the lesbian body under siege, continue and expand on these concerns.

${ }^{11}$ Pose attempts to be faithful to the documentary feel and aesthetics of Paris is Burning, even relying on the single camera set-up.

${ }^{12}$ On the more specific question of 'indexicality', live-action analogue media capture does not necessarily define documentary. The index / icon categories drawn from Charles Peirce might not hold up in all contexts (as in, for example, animated documentary, which can rely on 'indexical' sound but operates and is received in rather different auditory and sensory ways to live action).

${ }^{13}$ Howes has argued: 'While it is only possible to recognize visual culture, taste culture, sound studies, and so forth as flowing into sensory studies in retrospect (since the term 'sensory studies' did not exist, or was not used in this way, prior to 2006), it is nevertheless apparent that these previously independent streams now form a vast, fast-flowing river. Indeed, it could be said that the sensory turn - or, better, revolution - now rivals the linguistic turn of the 1960s and 1970s in terms of its impact on scholarship in the humanities and social sciences' (Howes 2013).

${ }^{14}$ A key text is Richard E. Cytowic's Synesthesia: A Union of the Senses (1989).

${ }^{15}$ Exceptions include Mellor (2009), MacDonald (2002), Smaill (2009). Nichols revisits the concept in 'Embodied Knowledge and the Politics of Location' (Nichols 1994: 1-16).

${ }^{16}$ I want to warmly thank Silvia Mergenthal and Melanie Stengele for organising the conference 'Visual Culture and Inequality' at the University of Konstanz. This article is a revised version of my keynote presented there. 